\title{
China, the USA, and Asia's Future
}

\section{Citation}

Saich, Anthony. "China, the USA, and Asia's Future. 2012. HKS Faculty Research Working Paper Series RWP12-052, John F. Kennedy School of Government, Harvard University.

\section{Published Version}

http://web.hks.harvard.edu/publications/workingpapers/citation.aspx?Publd=8671

\section{Permanent link}

http://nrs.harvard.edu/urn-3:HUL.InstRepos:9924087

\section{Terms of Use}

This article was downloaded from Harvard University's DASH repository, and is made available under the terms and conditions applicable to Other Posted Material, as set forth at http:// nrs.harvard.edu/urn-3:HUL.InstRepos:dash.current.terms-of-use\#LAA

\section{Share Your Story}

The Harvard community has made this article openly available.

Please share how this access benefits you. Submit a story.

\section{Accessibility}




\section{China, the USA and Asia's Future Faculty Research Working Paper Series}

\section{Tony Saich}

Harvard Kennedy School

\section{November 2012 RWP12-052}

Visit the HKS Faculty Research Working Paper series at: http://web.hks.harvard.edu/publications

The views expressed in the HKS Faculty Research Working Paper Series are those of the author(s) and do not necessarily reflect those of the John F. Kennedy School of Government or of Harvard University. Faculty Research Working Papers have not undergone formal review and approval. Such papers are included in this series to elicit feedback and to encourage debate on important public policy challenges. Copyright belongs to the author(s). Papers may be downloaded for personal use only. 


\title{
China, the USA and Asia's Future
}

\author{
Tony Saich
}

Harvard Kennedy School

Draft Prepared for the 20 $0^{\text {th }}$ Doyukai Symposium

Cambridge, June 2012

(Revised August 2012) 
Two major trends will define the future of Asia in this century: one economic, the other geopolitical. While economic integration has proceeded apace, there has not been the same kind of political integration that has marked Europe since the Second World War. At the core of both trends is the relationship between the US and China. China's economic rise and its more assertive diplomacy has created a new environment for neighboring countries to react to. This has necessitated other powers in Asia to work within a regional order that is no longer based on US primacy as the key guarantor of global and regional public goods. Despite relative decline, the Obama administration first with its unwieldy phrase of a pivot to Asia and the later notion of rebalancing has indicated clearly that it intends to retain a key role in Asia. The potential danger that this can give rise to is shown by the tension that arises periodically over territorial disputes. Most recently, there have been three unsettling trends. First, is the dispute between the Philippines and China over the Scarborough Shoal, which falls within the long tongue of the South China Seas that China claims as a "core interest." Second, in mid-June 2012, China announced that it had set up a prefectural city, Sansha, to oversee the three South China Sea islands of the Spratlys, the Paracels and Macclesfield Bank. Third, ther has been yet another escalation of sovereignty claims over the Senkaku (Diaoyu) islands between China and Japan. There have also been territorial spats between Japan and South Korea. Whether the US will be drawn into an avoidable conflict by its allies in the region or whether it will renege on its alliances to maintain a viable relationship with China heightens the insecurity. Below, we review the economic and geopolitical pictures before making some concluding comments. 
Asia's Economic Rise and China's Central Role in the Global Production Chain

In addition to the collapse of the Soviet Empire, the most important development of the last century was the steady, often spectacular rise of the Asian economies. Not only are they major players in global economic development but also the latest success story, China, is naively looked to as a savior of the European Union and the USA. This economic growth has been unusually beneficial not only for the countries in Asia but also for the economies that they are eclipsing. In historical terms this is unusual with new economic powers supporting the status quo and enhancing it rather than challenging it. The key question looking forward is whether China will also become status quo enhancing of whether its continued rise will lead to it challenging the global order. While some observers see China's rise as a threat, by and large, China has sought to bring its practices in line with global norms and has not sought to change the rules of the game, or the structure of international institutions. Indeed it is hard to think of a country that has benefitted more than China from the current global order. As John Ikenberry has written "Today's Western order is hard to overturn and easy to join." Asia's economic ascent, with China at the forefront, should continue but how political structures will accommodate this is harder to predict.

There has always been a leader of the "flying geese" pattern of development: first, Japan, followed by the four tigers in the 1970s with their focus on the promotion of export-led growth; ASEAN members in the 1980s; and in the 1990s, we have witnessed China's rise, followed by India. There is a strong national 
aspiration for development and the existence of models to aspire to has propelled this process forward.

However, not all countries in Asia have been successful in sustaining their economic breakthrough and certain countries have seen growth slow and income levels level off. Most of Southeast Asia grew quite rapidly for a period of time and then slowed down. Malaysia experienced a long period of expansion from 19691995 - real GDP grew at 7\% per annum. Indonesia grew at 6.8\% from 1967-1996. Thailand grew at 7.6\% for almost 40 years. Yet growth in all three has slowed to 4$6 \%$ and this slow down has occurred at relatively low levels of income per capita: $\$ 1280$ in Indonesia; $\$ 2700$ in Thailand; and under \$5000 in Malaysia. By contrast, incomes per capita in South Korea and Taiwan now exceed $\$ 15,000$, together with Hong Kong, Singapore and Japan.

The East Asia economies have sustained higher rates of economic growth for longer periods of time. Southeast Asian nations remain reliant on low-cost labor and natural resource exploitation. With the exception of Malaysia, Southeast Asian countries have all experienced extended periods of political and social turmoil. Governments are weakened by corruption and money politics. Mass protests and military coups have overthrown governments in Indonesia, Thailand and the Philippines. Urbanization has proceeded in a haphazard manner. East Asia countries have produced prosperity, stability, and international respect. Southeast Asia has followed a more circuitous route to a tenuous present and an uncertain future with inequality and instability as key features. It remains to be seen which path those 
next in line, China, Vietnam, and India will follow. There is much discussion within China as to whether it will escape the "middle income trap."

This economic development and functional integration has not been accompanied by the kind of regional political institutions that might ensure stability across Asia as a whole. One interesting development was the convening in December 2005 of the first joint summit of Asian nations with the intent to build some kind of an East Asian Community. This extended from India through South East Asia and would include China, Japan, and South Korea. However, already there were considerable differences about what the core of the community should be. China would like to see ASEAN plus three at the core, while it is clear Japan sees Australia and India playing an important role. At the 2011 meeting the original 16 was expanded to 18 to include the US and Russia.

Some form of organizational development along these lines is necessary as despite the tremendous economic progress in the region and the even greater economic potential, there is no truly effective regional apparatus that can bind together the diverse and often competing nations. APEC, ASEAN plus three and ARF have been beneficial but have not worked in the way that the European Union and other European institutions have in terms of healing the wounds of War and later providing a vehicle for integrating the former communist nations of Eastern Europe. However, of course, from its origins and with its subsequent expansions, the European Union was based on a shared notion of not only market principles but also the rule of law and a particular form of political organization underpinned by a remarkably similar culture. This is why the question of Turkish membership is so 
contentious and why the problems have occurred with the expansion of the Eurozone to the countries of the South. In Asia, the necessary conditions are still absent, which makes positive integration a difficult challenge. There are divergent views on the rule of law, major differences in political systems, and pre-existing territorial disputes and historical conflicts that have not been resolved as successfully as in Europe. Now, there is also China's pressure on certain countries within ASEAN that might make consensual decision-making more difficult. This was seen in 2012 when, for the first time at the Phnom Penh meeting, ASEAN did not issue a joint statement. It was rumored that China was unhappy about potential statements covering sovereignty in the South China Sea and put pressure on its quasi-satellites, Kampuchea and Laos, to resist the joint statement.

\section{China, the US and the Geopolitical Order}

The preceding analysis casts doubt on the notion of an Asian century. While it is true that we are dealing with a resurgent Asia and one that will carry more weight in economic and political decision-making moving forward, the chances of any country in the region or the region as a whole replacing the dominance of the US is extremely unlikely. The region is too diverse and divided to present a coherent challenge, even should it wish to do so. For example, the rise of China is causing other alliances to form such as an emerging relationship between Japan and India. The world may become multi-polar on some issues, a good thing, but it will be a very long time before a new unipolar world based on any country in Asia could 
emerge. This means that the major challenge is to devise structures that can integrate China and the US into an effective framework.

This makes understanding China's international behavior crucial. As noted, recent moves by China have cemented the sense among some nations in the region that they would not be comfortable with an institutional architecture based on Chinese hegemony, even more uncomfortable than one reliant on the US. There is concern that the US refocus on Asia and China's renewed assertiveness could lead to a period of friction and uncertainty. The definition of the "South China Sea" as a "core interest" for China and its nine-dash line are equally unsettling.

China's foreign policy and international behavior have been shaped by two key drivers that can operate in harmony but, on occasion, can operate in conflict. The first is an emotional driver that is closely linked to deep nationalist sentiment and often xenophobia and draws on China's history of what the Chinese Communist Party (CCP) refers to as "national humiliation" at the hands of the foreign powers. This still underlies the strength of feelings about the reunification of Taiwan and a lingering suspicion of foreign powers when dealing with China. It underpins China's assertion of sovereignty over disputed waters, islands and territories and makes the leadership in Beijing vulnerable to criticism if it is seen to be weak on questions of sovereignty.

Second, a more pragmatic driver is linked to China's desire to be an important player on the world stage, but that recognizes that in order to achieve this, the country needs to be seen as pragmatic and essentially a status quo power, one that is focused on economic growth as a primary policy goal. This drives China's 
entry into WTO and its embrace of the market and international trade and investment. It has seen China become the key country in the global manufacturing chain.

Under Deng Xiaoping and his successors, the pragmatic driver remained paramount and still does today. However, CCP legitimacy depends increasingly on maintaining economic growth to raise living standards, underpinned by appeals to nationalism (to replace discredited Marxism-Leninism). This unprecedented level of integration in world energy markets, in foreign reserve accumulation and in the process of climate change is forcing a fundamental change in China's former passive international position. The leadership under Hu Jintao and Wen Jiabao has been more energetic in promoting an independent foreign policy based on China's own strategic interests while trying to assure neighboring countries that China's increased economic strength will bring benefits to all concerned. In part this may be a natural development given that China's global engagement is now extensive and it is both more dependent than ever before on the health of the world economy and the support of its neighbors as well as impacting significantly on their development. It is the major trading partner now for South Korea and Japan. This has set challenges for how countries in the region (and also the US) should respond.

The dedication to sovereignty and a territorial definition of China that is the most expansive in history, and China's reluctance to move discussions out of bilateral frameworks, causes uncertainty in the region that has only been partially moderated by the economic opportunities. It also means that China is more willing to join regimes that govern the international economy, but is less enthusiastic about 
those regional or global frameworks that would place real restrictions on Chinese military capabilities. The CCP and the military have been adamantly opposed to any attempts to establish an Asian collective security system, primarily because they do not wish to give Southeast Asian nations a forum in which to criticize collectively its claims to sovereignty in the South China Sea.

Under Hu Jintao, China has tried to develop a more coherent Asia policy. At the conceptual level, China has promoted the slogan of "peace and development" (first used by Hu at the Baoao Forum in May 2005) as a response to those who see the country's rise as a current and, more importantly, a future threat. At the regional level, China has been promoting the idea of regional security. China's increased acceptance of multilateral frameworks to promote its national interest has stemmed from two sets of experiences. First, China has led the Shanghai Cooperation Organization that brings together Central Asian states with China to discuss security and other issues. The importance that Beijing attaches to this organization is shown by the fact that it has moved the headquarters from Shanghai to the Capital. Second, the experience of working with the ARF that it joined in 1994 has also been beneficial. China sees it as an opportunity through which it can reduce suspicion about Chinese power and to reduce US influence without undermining the relationship with the US. However, military confidence building measures through the ARF remain inadequate.

Despite the progress from Beijing's perspective, China's relations with Asia face three general challenges and four specific problems. First, as noted, China needs to keep convincing neighbors that its economic growth and increased strength will 
be of benefit to all rather than at the expense of its neighbors. Not all will agree with China's "win-win" scenarios, especially farmers who are priced out of the market by the import of cheap agricultural products. Second, there remains the need to develop new institutions and a framework that will allow countries in the region to cooperate effectively. Third, China's increased influence in the region needs to be pursued in a manner that does not challenge, at least in the short to medium-term, US fundamental interests. For other countries to accept a partial withdrawal of the US would mean that China would have to take their interests into account and even give up its expansive view of sovereignty and enter into new security arrangements so that they would not need to rely on the US security umbrella. This strategic intent of fighting local wars under hi-tech conditions does not inspire confidence that this will be the case.

The potential for friction is apparent in all four specific challenges. First, despite the improved relations with the return of the KMT to power on Taiwan, cross-straits relations still lack a long-term vision. Second, there is the instability on the Korean peninsula and the North Korean nuclear ambitions. It is clear that China is frustrated with North Korean behavior but is concerned about the adverse consequences of regime collapse. Third, there are the aforementioned territorial claims in the South China Sea and elsewhere. Last but not least, there is the question of long-term leadership in the region. This involves China, Japan, and the US and, in particular how well China and Japan can accommodate each other. This latter relationship is highly unpredictable and potentially very volatile. Despite the obvious compatibility of the two economies, two-way trade and investment has 
suffered because of the problems and Japanese economic involvement in China remains far below its potential. A functioning relationship needs to be established in order to prevent long-term uncertainty in the East Asian region. The renewal of the US-Japan security guidelines has caused Beijing concern and heightened its view that Japan plays an important role in the US attempts to constrain China. Similar suspicions exist in Beijing about more recent US agreements with Australia.

While there is justifiable concern about China's military development, there are still constraints on its activities. China's defense spending has remained relatively constant over the past 15 years at roughly $8 \%$ of GDP, despite large total increases. It face real limits on what it can spend for maritime defense and regional force projection capabilities. Even the Pentagon's highest calculation was $\$ 139$ billion in 2007, just slightly less than the budget for US Navy ( $\$ 147$ billion). Last but not least, the US presence in Maritime East Asia remains strong.

\section{Concluding Comments}

It is even more important for the US and China to find a way to cooperate in the Asia region than it is for the other countries within the region. There is no alternative leader within the region or group of countries that can provide the kind of balance that will enable the necessary public goods to be produced (maritime safety, climate control etc.). This will entail modification of behavior by both the US and China and it will not be easy.

China's strategic goals are directed to the defense of a continental power with growing maritime interests, as well as to Taiwan's unification and other 
sovereignty claims and are largely conservative, not expansionist from their own perspective. However, China's neighbors may not view this in the same way. China's continued economic rise may nevertheless spawn a new security dilemma in East Asia, increasing regional instability and undermining China's attempts at the diplomacy of reassurance. China has always shown itself willing to use force to protect what is sees as "legitimate" territorial claims.

To be effective, both the US and China will have to make accommodations. China will have to define its national interest more clearly and this will mean acknowledging that other principles of its foreign policy may be overridden under certain circumstances. Its principle of non-interference has become ineffective in dealing with North Korea and its increased overseas investment means that its commercial activities are increasingly pulling China's foreign policy into the internal affairs of other countries. Whether China acknowledges it or not, its commercial activities have become a major issue in the domestic politics of a number of countries in the region. China needs to be able to feel comfortable with the framework for international governance that it is now a key member of. Many important issues beyond the directly political and economic, such as environmental protection, drug smuggling, trafficking in women, and HIV/AIDS, need China's active participation to resolve. China needs to reduce its suspicion of hostile foreign intent and adjust its outdated notion of sovereignty to accept that some issues need transnational solutions and that international monitoring does not have to erode CCP power. 
For its part, the US and other nations in the region need to incorporate China as a more equal partner and to build China's reasonable concerns into the architecture of international governance. The US will have to adjust to the fact that the rise of Asia and China in particular means that while a new global order will not be multipolar, it will necessitate the US accepting that it needs to work within frameworks of partnership rather than presuming the global order is one dictated by Washington. Without accommodation on both sides, China will remain a rather grumpy, unpredictable player in international governance and security in the Asia region will remain unpredictable. 